\title{
Dukungan Sosial Orang Tua dan Self-Esteem (Penelitian Terhadap Tim Kabupaten Sumedang di Ajang O2SN Jawa Barat)
}

Anggi Setia Lengkana a ${ }^{a}$ Ayi Suherman ${ }^{b}$, Rana Gustian Nugraha ${ }^{c}$, Entan Saptanid*

a,b,c,d Universitas Pendidikan Indonesia, Indonesia

Correspondence: asetialengkana@upi.edu

Received: 30 Oct 2019 Accepted: 21 Apr 2020 Published: 29 Apr 2020

\begin{abstract}
This study aims to determine the effect of parental social support on the district team. Sumedang in the O2SN elementary school level in West Java. The method used is an associative method with survey design. The research design used is cross-sectional. The instrument used was a questionnaire for Parents' Social Support and the Hare Self-esteem Scale (HSS). The research location is in Sumedang Regency. The population is elementary students who are members of the district team. Sumedang to attend the O2SN West Java Province. The results showed that social support has a great influence on self-esteem. This is evidenced by the significance test of variable $\mathrm{X}$ to $\mathrm{Y}$ which shows the results of $\mathrm{Y}=\mathrm{a}+\mathrm{b} \mathrm{X} 1=222,109+0.729 \mathrm{X} 1$ The percentage obtained between $\mathrm{X}$ to $\mathrm{Y}$ is $0.405 \times 100 \%=40.5 \%$. Parental social support has a significant influence on self-esteem. This is evidenced by an increase test that shows the value of tcount with ttable, it turns out that tcount $=4.568$ is greater than ttable $=1.697$, or the value of sig. smaller than the 0.05 significance level that is 0.047 , so it can be concluded that the Social Support $(\mathrm{X})$ regression equation against Self esteem (Y) is significant. The conclusion of the research shows that there is a great influence given by the social support of parents on children's self esteem.
\end{abstract}

Keywords: elementary school students; parental social support; self-esteem

\begin{abstract}
Abstrak
Penelitian ini bertujuan untuk mengetahui pengaruh dukungan sosial orangtua pada tim kab. Sumedang di ajang O2SN Sekolah Dasar tingkat Jawa Barat. Metode yang digunakan adalah metode asosiatif dengan rancangan survei. Desain penelitian yang digunakan adalah Cross-Sectional. Instrumen yang digunakan berupa angket Dukungan Sosial Orang Tua dan Hare Self-esteem Scale (HSS). Lokasi penelitian bertempat di Kabupaten Sumedang. Populasi adalah Siswa Sekolah Dasar yang tergabung dalam tim Kab. Sumedang untuk mengikuti ajang O2SN Provinsi Jawa Barat. Hasil penelitian menunjukkan bahwa dukungan sosial memiliki pengaruh besar pada self-esteem. Hal ini dibuktikan dengan uji signifikansi variabel $\mathrm{X}$ terhadap $\mathrm{Y}$ yang menunjukkan hasil $\mathrm{Y}=\mathrm{a}+\mathrm{b}$ X1 $=222,109+0,729 \mathrm{X} 1$ Persentase yang diperoleh antara X ke Y adalah 0,405 x 100\% $=40,5 \%$. Dukungan sosial orang tua memiliki pengaruh signifikan terhadap self-esteem. Ini dibuktikan dengan uji kenaikan yang menunjukkan nilai thitung dengan $\mathrm{t}$ tabel, ternyata $\mathrm{t}$ hitung $=4,568$ lebih besar dari $\mathrm{t}$ tabel $=$ 1,697, atau nilai sig. lebih kecil dari tingkat signifikansi 0,05 yaitu 0,047, sehingga dapat disimpulkan bahwa persamaan regresi Dukungan Sosial $(\mathrm{X})$ terhadap harga diri (Y) adalah signifikan. Kesimpulan penelitian menunjukkan bahwa ada pengaruh besar yang diberikan oleh dukungan sosial orang tua terhadap self-esteem anak.
\end{abstract}

Katakunci: siswa sekolah dasar; dukungan sosial orangtua; harga diri 


\section{Pendahuluan}

Orang tua merupakan kunci keberhasilan bagi anak-anaknya untuk meraih sukses di dalam hidupnya pada masa yang akan datang. Orang tua harus mengerti betul bahwa pendidikan anak tidak cukup hanya di sekolah, karena masih banyak waktu luang yang harus diisi dengan kegiatan yang positif. Sebagai orang tua tugas memotivasi anaknya untuk belajar tentunya tidaklah mudah seperti yang dibayangkan, karena banyak sekali faktor-faktor yang berpengaruh terhadap keberhasilan anaknya dalam pendidikan. Orang tua mempunyai peranan yang sangat penting dalam memotivasi dan mengarahkan pendidikan anak-anaknya baik pendidikan moral, tingkah laku, akhlaq dan pendidikan non formal lainnya termasuk di antaranya tentang minat dan bakat anaknya dibidang olahraga prestasi.

Hubungannya dengan pembinaan prestasi olahraga di antaranya dapat dicapai dengan cara turut serta berlatih di klub-klub olahraga yang tersedia di daerah. Sebuah klub merupakan suatu media bagi anak untuk dapat lebih menyalurkan hobi yang mereka cintai dengan tujuan supaya regenerasi prestasi terus terjaga. Prestasi olahraga Menurut (Sumoprawiro, 2009) merupakan, 'pencapaian akhir yang memuaskan oleh seseorang atau tim, berdasarkan target awal yang dibebankan'. Oleh karena itu, sebuah prestasi tidak selalu diibaratkan dengan kemenangan. Walaupun tidak mencapai kemenangan, tetapi bila itu sudah dapat melampaui target semula, itu sudah dapat disebut prestasi. Sebuah prestasi yang didapat pada dasarnya merupakan sebuah hasil interaksi beberapa faktor. Oleh sebab itu, pelatih perlu mengetahui faktor tersebut guna dapat mempengaruhi prestasi atletnya dalam upaya membantu atlet untuk dapat mencapai prestasi yang sebaik mungkin. Faktor tersebut adalah: (a). Diri sendiri; 1). Jasmani 2). Psikologis; a). Pengetahuan Rasionalisme yang dimana pengetahuan ini meliputi faktor dalam hal kecerdasan dan bakat yang dimiliki oleh seseorang, b). Pengetahuan Nonrasionalisme, seperti keinginan karena kebutuhan, motivasi, emosi dan penyesuaian diri. 3). Kesiapan fisik; (b). luar diri: sosial (lingkungan sekitar baik lingkungan keluarga, sekolah dan masyarakat); budaya (adat istiadat, ilmu pengetahuan, teknologi, dan kesenian); sarana dan prasarana seperti (fasilitas rumah dan fasilitas belajar dan fasilitas berlatih); lingkungan spiritual atau keagamaan (Sumoprawiro, 2009).

Pencapaian prestasi lebih terpengaruh oleh faktor jasmani dan psikologis. Mengenai faktor-faktor internal tersebut akan dikhususkan pada faktor psikologis. Kehadiran faktor psikologis, bisa mempengaruhi jalan ketercapain prestasi, bahkan memungkinkan untuk dapat menambah kesulitan ketika anak berlatih. Faktor psikologis yang dimaksud diantaranya ialah motivasi. Motivasi seseorang akan dinyatakan berhasil ketika mereka berlatih dan bertanding, jika dalam dirinya terdapat keinginan untuk berprestasi lebih baik. Inilah merupakan prinsip dari kegiatan olahraga prestasi. Motivasi dalam hal ini meliputi dua hal: (1) seseorang tau apa yang akan dilakukannya, dan (2) dia paham mengapa melakukannya. Dengan berpedoman kepada kedua unsur motivasi tersebut maka inilah sebagai dasar permulaan yang baik untuk berlatih. Tanpa adanya kegiatan latihan sangat sulit untuk berhasil, karena segala sesuatu harus berproses tidak dapat dicapai dengan instan. Sedangkan faktor eksternal salah satunya adalah dukungan dari orangtua (faktor keluarga). Anak yang berkecimpung dalam olahraga prestasi akan mendapatkan pengaruh dari keluarga, salah satunya adalah mendapatkan didikan dari orang tuanya, bentuk dukungan orang tua, hubungan antar anggota keluarga, suasana dalam keluarga, pengertian dan perhatian orang tua serta latar belakang kebudayaan juga menjadi faktor yang mempengaruhi ketika seorang atlet dihadapkan kepada faktor psikologis (Myers-Clack \& Christopher, 2001). Jadi oleh karenannya baik itu motivasi berprestasi maupun dukungan sosial dari orangtua merupakan faktor psikologis yang mempengaruhi kinerja atlet itu sendiri dalam pencapaian prestasi.

Olahraga prestasi akan dapat berhasil apabila dilakukan sejak anak usia muda, namun secara berkelanjutan dan terkoordinasi dengan baik melalui bimbingan dari pembina olahraga. Salah satu 
klub cabang olahraga atletik yang hingga sekarang terus menetaskan bibit-bibit atlet potensial dimasa depan ialah Sekolah Atletik Pajajaran yang berlokasi di Stadion Pajajaran Kota Bandung. Orang tua akan mengarahkan dan memotivasi anaknya agar memilih cabang olahraga sesuai dengan bakat dan minat, yang nantinya dapat bermanfaat bagi dirinya dan juga bisa membawa nama baik orangtua atau keluarga bahkan negara dan bangsa. Orang tua memiliki peran utama dalam memelihara dan mengembangakan motivasi anak. Sebab, orang tua adalah panutan, pendidik pertama anak ketika di rumah. Menurut (Stainback \& Stainback, 2001) peran orang tua meliputi: (1) Orang tua sebagai fasilitator, (2) Orang tua sebagai motivator, (3) Orang tua sebagai pembimbing atau pengajar.

Penjelasan di atas tergambar jelas bahwa sangatlah penting peran serta orang tua ketika anak melakukan berbagai kegiatan belajar, atau olahraga prestasi. Sebaiknya orang tua bisa memfasilitasi belajar yang memadai, memberikan motivasi tinggi serta memberikan bimbingan kepada anak selama proses belajarnya. Bloom (Akbar, 2001) menjelaskan mengenai dorongan sosial orang tua merupakan hal yang paling mendasar perlu diperhatikan untuk dapat mencapai tujuan belajar anak yang lebih baik. Bentuk dukungan orang tua bisa dibuktikan dengan pemberian kasih sayang, perhatian dan penguatan baik dalam bentuk penghargaan, diharapkan dalam diri anak bisa tumbuh mental yang baik. Untuk mendapatkan sebuah prestasi yang baik tidak mungkin didapat begitu saja tetapi diperoleh melalui usaha dan kerja keras, sehingga perlu mempersiapkan diri dengan matang baik itu pada aspek kondisi fisik, teknik, taktik maupun psikologis berupa dukungan orangtua. Self esteem pun merupakan output penentu ketercapaian prestasi anak ketika dukungan sosial dari orangtua sangatlah besar, (Linver, Brooks-Gunn, \& Kohen, 2002) menjelaskan bahwa self esteem sangat berkaitan dengan kedua faktor yaitu: 1) Perasaan individu seseorang bahwa dirinya bisa dan dibutuhkan, 2) Jumlah dukungan sosial yang didapatkan seseorang dari orang lain. Seseorang dengan tingkat self esteem yang baik dapat merasa baik dalam situasi apapun dan apabila seseorang dengan self esteem yang rendah akan merasa diri mereka tidak mampu melakukan dengan percaya diri karena merasa tidak ada dukungan.

Dimana dukungan, keberadaan, juga bantuan orangtua sangat penting dalam mendukung anak pada saat latihan dan bertanding. Hal ini sesuai dengan hasil penelitian Clement, Damien and Shannon, Vanessa R. menjelaskan bahwa, "the direct-effects theory, on the other hand, suggests that the quantity and efficacy of social support impacts psychological and physical well-being" (Clement \& Shannon, 2011). Apabila diterjemahkan teori menyatakan efek langsung, di sisi lain, menunjukkan bahwa jumlah dan efektivitas dukungan sosial mempengaruhi kesejahteraan psikologis dan fisik. Artinya, semakin efektif menerima dukungan sosial maka psikologis dan fisik individu akan lebih sejahtera, dan sedangkan yang kurang menerima dukungan sosial maka, kurang mampu secara psikologis dan secara fisik.

Berdasarkan hasil pengamatan penulis dilapangan, banyak orangtua yang mengikutsertakan anakanaknya pada kegiatan pelatihan olahraga di Kabupaten Sumedang, khususnya pada siswa sekolah dasar pada persiapan O2SN Provinsi Jawa Barat. Namun masih banyak beberapa anak yang mengikuti kegiatan tersebut yang tidak didampingi oleh orangtuanya, dikarenakan kesibukan orangtuanya yang bekerja. Sedangkan apabila dilihat dari usia mereka masih sangat membutuhkan perhatian yang lebih dari orangtua. Mereka berangkat ke tempat latihan bersama-sama dengan teman lainnya yang didampingi orangtua, karena ada beberapa dari mereka yang satu sekolah ataupun lokasi sekolahnya berdekatan. Ini menjadi dilema bagi anak-anak dan pelatih, karena ini menjadi sebuah bagian yang penting untuk motivasi si anak berlatih dan pencapaian prestasi tentunya. Oleh karenanya penulis tertarik untuk melakukan penelitian dengan judul "Dukungan Sosial Orang Tua dan Self-Esteem pada Tim Kabupaten Sumedang di Ajang O2SN Jawa Barat 2019”. 


\section{Metode Penelitian}

Penelitian ini dilakukan selama dua belas minggu dengan uraian waktu, minggu kesatu sampai ke empat dilakukan pengenalan materi, minggu kelima sampai minggu kedua belas dilakukan pengambilan data penelitian, dikarenakan lokasi latihan yang berjauhan. Penelitian ini dilakukan di SD Se-Kabupaten Sumedang karena lokasi latihan tiap cabang olahraga yang berjauhan, oleh karenanya pengambilan data penelitian dilakukan dibeberapa lokasi.

Dalam penelitian ini penulis menggunakan metode asosiatif dengan rancangan survei. Survei adalah penyelidikan yang diadakan untuk memperoleh fakta-fakta dari gejala-gejala yang ada dan mencari keterangan-keterangan secara faktual (Maksum, 2012). Penelitian ini menggunakan Cross-Sectional Design. Desain ini mengukur dan mengamati secara simultan pada satu saat untuk mencari hubungan sebab akibat antara variabel bebas dan variabel terikat.

Populasi dalam penelitian ini adalah seluruh atlet pada tim Kabupaten Sumedang di ajang O2SN Jawa Barat 2019. Teknik sampling yang digunakan adalah sampling jenuh, alasan menggunakan teknik karena berdasarkan keterjangkauan peneliti.

Instrumen yang digunakan dalam penelitian ini adalah angket dan tes. Pemilihan instrumen sesuai dengan variabel yang akan diukur yaitu dukungan sosial orangtua (Fischer \& Corcoran, 2007) dan Hare Self-esteem Scale (HSS) (Lengkana, 2013) sebagai alat pengumpulan datanya.

Dukungan sosial orang tua di uraikan menjadi empat aspek yaitu dukungan emosional, dukungan penghargaan, dukungan instrumental dan dukungan informatif. Setiap aspek diuraikan menjadi beberapa indikator, kemudian disusun menjadi butir pernyataan. Didapatlah 31 butir pernyataan pada angket dukungan sosial orang tua. Rancangan angket dukungan sosial orang tua dapat dilihat pada kisi-kisi dibawah ini.

Tabel 1. Kisi-kisi Skala Dukungan Sosial Orang Tua

\begin{tabular}{clc}
\hline Aspek & \multicolumn{1}{c}{ Indikator } & Nomor Pernyataan \\
\hline Dukungan & 1. Empati & $1,2,3,4$ \\
Emosional & 2. Kepedulian & $5,6,7$ \\
& 3. Perhatian & $8,9,10,11$ \\
Dukungan & 1. Penghargaan positif & $12,13,14$ \\
Penghargaan & 2. Persetujuan gagasan & $15,16,17$ \\
& & \\
Dukungan & 1. Bantuan langsung berupa barang/uang & $18,19,20$ \\
Instrumental & 2. Bantuan langsung berupa tindakan & $21,22,23,24$ \\
& 1. Nasehat & $25,26,27$ \\
Dukungan & 2. Saran & 28,29 \\
Informatif & 3. Petunjuk & 30,31 \\
\hline
\end{tabular}

\section{Hare Self-esteem Scale (HSS)}

Kisi-kisi angket Self-Esteem yang lebih rinci dapat dilihat pada tabel 2. 


\section{Tabel 2. Kisi-kisi Angket Self-Esteem}

\begin{tabular}{|c|c|c|}
\hline Sub Komponen & Indikator & No. Item \\
\hline Motif berprestasi & $\begin{array}{l}\text { Percaya diri dengan kemampuannya } \\
\text { untuk melaksanakan sesuatu pekerjaan } \\
\text { Memahami kemampuan dan potensi diri } \\
\text { Sulit berprestasi }\end{array}$ & $26,21,16,29$ \\
\hline Kepercayaan diri & $\begin{array}{l}\text { Percaya diri atas kemampuan dan potensi } \\
\text { diri } \\
\text { Pesimis } \\
\text { Tidak menerima keadaan diri sendiri } \\
\text { Percaya diri bahwa kemampuan dan } \\
\text { potensinya tidak kalah dengan orang lain } \\
\text { Percaya dirinya rendah }\end{array}$ & $\begin{array}{l}3,7,11,13,17,19, \\
24,28,5,9,12,14, \\
25,8,20,22,6,23\end{array}$ \\
\hline Perasaan diri & $\begin{array}{l}\text { Memahami bahwa setiap orang memiliki } \\
\text { kelebihan dan kekurangan masing-masing } \\
\text { Merasa pantas } \\
\text { Merasa tidak pantas } \\
\text { Merasa tidak berguna bagi orang lain }\end{array}$ & $15,30,18,27,10$ \\
\hline Penghargaan diri & $\begin{array}{l}\text { Aktif dalam hidup berkelompok } \\
\text { Tidak mampu memelihara hubungan } \\
\text { dengan orang lain } \\
\text { Tidak aktif dalam hidup berkelompok }\end{array}$ & $1,4,2$ \\
\hline
\end{tabular}

\section{Hasil}

Untuk dapat menganalisis, data yang diperoleh dari pengukuran tingkat dukungan sosial orangtua dan self-esteem yang menggunakan Hare Self-esteem Scale (HSS). Data selanjutnya dianalisis melalui uji statisitik untuk mengetahui tingkat self-esteem dan kebugaran jasmani dari masing-masing kelompok sampel.

Setelah dilakukan penghitungan dan penyekoran terhadap angket yang diteskan pada sampel, dan selanjutnya dianalisa menggunakan program SPSS Seri 17. Pada bagian ini penulis sajikan hasil analisis data secara sederhana berupa rangkuman. Untuk hasil analisis data secara lengkap, penulis uraikan pada bagian lampiran. Berikut ini adalah rangkuman dari hasil analisis data angket dukungan sosial dan HSS pada masing-masing kelompok.

Tabel 3. Deskripsi Data Dukungan Sosial dan Self-Esteem

\begin{tabular}{|c|c|c|c|c|}
\hline Kelompok & & & Statistic & Std. Error \\
\hline$\overline{\mathrm{DUKUNGAN}}$ & Mean & & 81.0667 & .39518 \\
\hline SOSIAL & $95 \%$ Confidence Interval for & Lower Bound & 80.2584 & \\
\hline & Mean & Upper Bound & 81.8749 & \\
\hline & 5\% Trimmed Mean & & 81.0926 & \\
\hline & Median & & 81.0000 & \\
\hline & Variance & & 4.685 & \\
\hline & Std. Deviation & & 2.16450 & \\
\hline & Minimum & & 77.00 & \\
\hline & Maximum & & 85.00 & \\
\hline & Range & & 8.00 & \\
\hline
\end{tabular}




\begin{tabular}{|c|c|c|c|c|}
\hline \multicolumn{3}{|l|}{ Kelompok } & \multirow{2}{*}{$\begin{array}{l}\text { Statistic } \\
3.25\end{array}$} & \multirow[t]{2}{*}{ Std. Erro } \\
\hline & Interquartile Range & & & \\
\hline & Skewness & & -.267 & .427 \\
\hline & Kurtosis & & -.678 & .833 \\
\hline \multirow[t]{13}{*}{ SELF-ESTEEM } & Mean & & 74.5667 & .49523 \\
\hline & $95 \%$ Confidence Interval for & Lower Bound & 73.5538 & \\
\hline & Mean & Upper Bound & 75.5795 & \\
\hline & $5 \%$ Trimmed Mean & & 74.5370 & \\
\hline & Median & & 74.5000 & \\
\hline & Variance & & 7.357 & \\
\hline & Std. Deviation & & 2.71247 & \\
\hline & Minimum & & 70.00 & \\
\hline & Maximum & & 80.00 & \\
\hline & Range & & 10.00 & \\
\hline & Interquartile Range & & 4.25 & \\
\hline & Skewness & & .083 & .427 \\
\hline & Kurtosis & & -.783 & .833 \\
\hline
\end{tabular}

Untuk kelompok sampel berjumlah 30, adapun rata-rata hasil tes tingkat dukungan sosial untuk kelompok siswa 81.0667 dan standar deviasi 2.16450 serta varians 4.685. Sedangkan skor terendah yang diperoleh adalah 77,00 dan skor tertinggi adalah 85,00.

Hasil tes tingkat self-esteem diperoleh rata-rata 74.5667 dengan standar deviasi 2.71247 serta varians 7.357. Sedangkan skor terendah yang diperoleh adalah 70,00 dan skor tertinggi adalah 80,00.

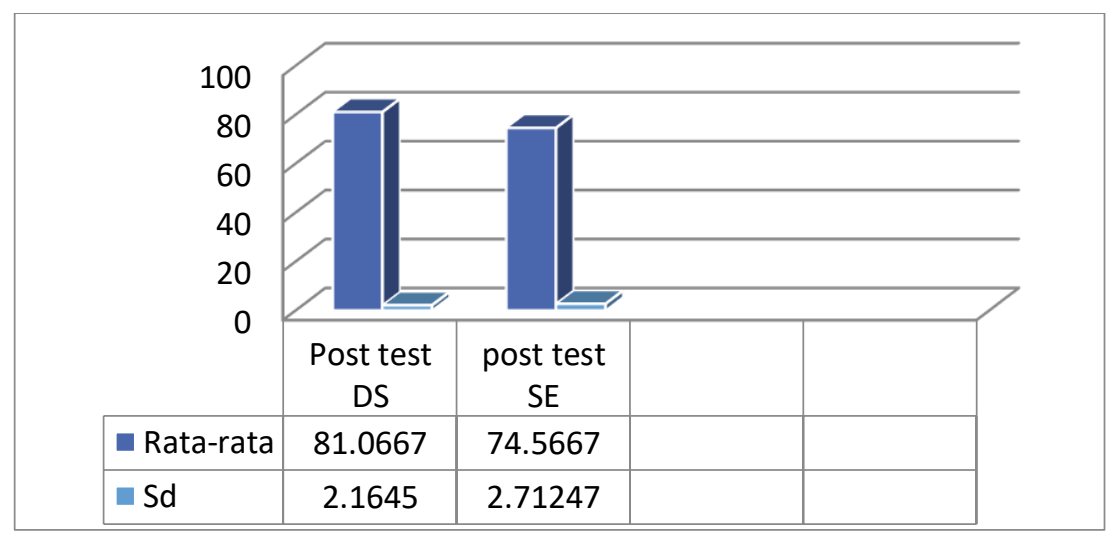

Gambar 1. Perbandingan Dukungan Sosial dan Self-Esteem

Langkah selanjutnya melakukan uji normalitas data. Uji normalitas data dilakukan untuk mengetahui apakah data yang diperoleh dan akan diuji berada pada taraf distribusi normal atau tidak. Selain itu, uji normalitas juga dilakukan untuk menentukan langkah uji statistik parametrik atau non-parametrik. Dalam uji normalitas data, penulis menggunakan bantuan program SPSS seri 17. Berikut ini adalah ringkasan hasil uji normalitas data tingkat dukungan sosial dan self-esteem.

Tabel 4. Hasil Uji Normalitas Dukungan Sosial dan Self-Esteem

\begin{tabular}{llll}
\hline \multicolumn{3}{l}{ Kolmogorov-Smirnov $^{\mathrm{a}}$} \\
\hline Statistic & Df & Sig. \\
\hline
\end{tabular}




\begin{tabular}{lccc}
\hline $\begin{array}{l}\text { Dukungan } \\
\text { Sosial }\end{array}$ & 0,134 & 30 & 0,182 \\
Self esteem & 0,157 & 30 & 0,057 \\
\hline
\end{tabular}

Untuk melakukan pengujian dari hasil output tersebut, ada beberapa langkah yang disajikan. Berikut ini adalah beberapa langkah dan ketentuan uji normalitas dari data pada tabel 4 .

Mengacu pada kriteria keputusan bahwa, nilai probabilitas (Sig.) untuk sampel yang diuji berdasarkan Kolmogorov-Smirnov diperoleh nilai Sig. lebih besar dari 0,05. Berdasarkan hasil analisis data tersebut, dapat disimpulkan bahwa data dukungan sosial dan self-esteem berada pada taraf distribusi normal.

Tahapan hitungan selanjutnya adalah uji linieritas regresi (X) dengan (Y), didasarkan pada perhitungan linieritas regresi yang dilakukan dengan menggukan aplikasi software SPSS versi 17. Adapun output dan interpretasi hasil perhitungannya dijelaskan sebagai berikut:

Tabel 5. Output SPSS (Anova Table) Memaparkan Uji Linieritas Regresi (X) dengan (Y)

\begin{tabular}{|c|c|c|c|c|c|c|c|}
\hline \multicolumn{8}{|c|}{ ANOVA Table } \\
\hline & & & Sum of Squares & df & Mean Square & $\mathbf{F}$ & Sig. \\
\hline \multirow{5}{*}{$\begin{array}{l}\text { Self Esteem * } \\
\text { Dukungan Sosial }\end{array}$} & Between & (Combined) & 8308.901 & 18 & 461.606 & .920 & .576 \\
\hline & Groups & Linearity & 157.556 & 1 & 157.556 & .314 & .586 \\
\hline & & $\begin{array}{l}\text { Deviation } \\
\text { from } \\
\text { Linearity }\end{array}$ & 8151.344 & 17 & 479.491 & .955 & .546 \\
\hline & \multicolumn{2}{|c|}{ Within Groups } & 6022.583 & 12 & 501.882 & & \\
\hline & \multicolumn{2}{|l|}{ Total } & 14331.484 & 30 & & & \\
\hline
\end{tabular}

Berdasarkan hasil Uji linieritas diketahui nilai Sig. deviation from linierity sebesar 0,546 $>0,05$, maka dapat disimpulkan bahwa linieritas regresi dukungan sosial $(\mathrm{X})$ dengan self esteem $(\mathrm{Y})$ berdistribusi linier.

Langkah berikutnya ialah Uji signifikansi regresi (X) dengan (Y) didasarkan pada perhitungan signifikansi regresi yang dilakukan dengan menggukan aplikasi software SPSS versi 17. Adapun output dan interpretasi hasil perhitungannya dijelaskan sebagai berikut:

Tabel 6. Output SPSS (Anova ${ }^{b}$ ) yang Memaparkan Uji Signifikansi Regresi (X) dengan (Y)

\begin{tabular}{llccccc}
\hline \multicolumn{7}{c}{ ANOVA $^{\mathrm{b}}$} \\
\hline & Model & Sum of Squares & Df & Mean Square & F & Sig. \\
\hline 1 & Regression & 157.556 & 1 & 157.556 & 5.122 & $.575^{\mathrm{a}}$ \\
& Residual & 14173.928 & 29 & 488.756 & & \\
& Total & 14331.484 & 30 & & & \\
a. Predictors: (Constant), Dukungan Sosial & & & & \\
b. Dependent Variable: Self esteem & & & & \\
\hline
\end{tabular}

Untuk menguji signifikansi regresi $(\mathrm{X})$ dengan $(\mathrm{Y})$ berdasarkan tabel ANOVAb di atas diperoleh nilai $F_{\text {hitung }}$ sebesar 0,322, sedangkan nilai $F_{\text {tabel }}$ dimana df 1:29 dengan taraf percaya 0,05 diperoleh nilai sebesar 4,18. Setelah membandingkan nilai $F_{\text {hitung }}$ dengan $F_{\text {tabel, }}$, ternyata teridentifikasi bahwa 
$F_{\text {hitung }}(5,122)$ lebih besar daripada $F_{\text {tabel }}(4,18)$ sehingga dapat disimpulkan signifikansi regresi dukungan sosial $(\mathrm{X})$ dengan self esteem $(\mathrm{Y})$ diterima.

Berikut ini akan dibahas mengenai model persamaan regresi (X1) dengan (Y) disusun berdasarkan output software SPSS versi 17 pada tabel coefficiensa. Adapun output dan interpretasinya dijelaskan sebagai berikut:

\section{Tabel 7. Uji Signifikansi Variabel X Terhadap Y}

\begin{tabular}{ccccccc}
\hline \multicolumn{8}{c}{ Coefficients $^{\mathbf{a}}$} \\
\hline \multicolumn{7}{c}{ Unstandardized } \\
Coefficients & Standardized \\
Coefficients & & \\
& Model & $\mathbf{B}$ & Std. Error & Beta & t & Sig. \\
\hline 1 & (Constant) & 222.109 & 32.367 & & 6.862 & .000 \\
& Dukungan Sosial & .729 & .492 & .405 & 4.568 & .047 \\
& & a. Dependent Variable: Self esteem & & \\
\hline
\end{tabular}

Pada uraian tabel tersebut di atas maka variabel dukungan sosial $(\mathrm{X})$ memaparkan pengaruh dengan cara parsial terhadap variabel self esteem $(\mathrm{Y})$ ditujukan untuk menguji hasil signifikansi dari konstanta dan variabel terikat. Untuk menyusun model persamaan dari regresi $\mathrm{Y}=\mathrm{a}+\mathrm{b} \mathrm{X} 1$ memiliki konstanta regresi dari a sebesar $=222,109$ dan besaran koefisien dari regresi $b=0,729$ X1. Maka model persamaan regresi linier sederhananya ialah $\mathrm{Y}=\mathrm{a}+\mathrm{b} \mathrm{X} 1=222,109+0,729 \mathrm{X} 1$ Persentase yang diperoleh antara X terhadap $\mathrm{Y}$ adalah $0,405 \times 100 \%=40,5 \%$.

Dalam menguji valid tidaknya hasil dari persamaan regresi maka, langkah selanjutnya yang harus dilakukan ialah uji t, berdasarkan hasil output SPSS pada tabel coefficiens ((a) maka, diperoleh nilai $t_{\text {hitung }}=4,568$, sedangkan nilai untuk $t_{\text {tabel }}=1,697$. Syarat untuk valid nilai sig. $<0,05$, atau $t_{\text {hitung }}>t_{\text {tabel }}$. Setelah membandingkan nilai dari uji $t$, maka thitung dengan $t_{\text {tabel, }}$, ternyata teridentifikasi bahwa $t_{\text {hitung }}$ $=4,568$ lebih besar daripada $t_{\text {tabel }}=1,697$, atau nilai sig. lebih kecil dari taraf signifkansi 0,05 yaitu 0,047, jadi dapat disimpulkan bahwa persamaan regresi untuk dukungan sosial $(\mathrm{X})$ terhadap self esteem (Y) adalah signifikan.

\section{Pembahasan}

Pada saat anak melakukan kegiatan yang dia sukai haruslah memiliki dukungan sosial orang tua, karena segala apapun yang akan dia lakukan akan berampak positif atau negatif (Caron, Weiss, Harris, \& Catron, 2006). Anak-anak tetaplah anak, meskipun mereka telah tejun kedunia profesional namun tetap saja dukungan orangtua sangatlah penting karena mereka masih dalam masa tumbuh dan berkembang. Hal ini sesuai dengan Pendapat (Mbong, 2017) yaitu 'Pengalaman yang menyenangkan selama melakukan aktivitas fisik dan olahraga dapat menumbuhkan self-esteem yang pada gilirannya dapat memunculkan motivasi untuk terus berpartisipasi dalam aktivitas fisik dan olahraga.' Partisipasi dalam hal ini bukan hanya dilakukan di lingkungan pembelajaran tetapi lebih luas lagi bisa dilakukan dalam lingkungan sosial siswa.

Program pembinaan pada olahraga prestasi hendaknya memperhatikan pertumbuhan dan perkembangan anak. Pembinaan jangan terlalu menuntut paksa agar anak menguasai suatu kompetensi tertentu yang justru akan mangakibatkan perasaan tidak nyaman dan tidak senang dalam berlatih. Anak harus dititik beratkan pada pengalaman gerak yang menyenangkan yang dibutuhan untuk perkembangan dan pertumbuhannya (Fisher et al., 2005). Program pembinaan multilateral harus diarahkan kepada suatu situasi yang menyenangkan, karena perasaan senang akan timbul 
berdampingan dengan perasaan sukarela hal ini merupakan dambaan setiap anak, sehingga guru ataupun pelatih harus berpikir kreatif dan inovatif dalam membuat formula program latihan bagi kegiatan ekstrakurikuler olahraga. Disamping itu pelatih haruslah bersinergi dengan berbagai pihak untuk dapat menggali informasi mengenai keseharian, kebiasaan anak tersebut, sehingga pengembangan potensi pada diri anak dapat dilakukan seoptimal mungkin dengan beberapa informasi terkait dukungan sosial.

Dukungan sosial adalah bentuk dukungan dari orang lain yang terjalin karena adanya sebuah stimulus dan respon, bentuknya bisa sebuah informasi, prilaku baik, penguatan dan bantuan secara materil maupun non materil (Setyaningrum, 2015). Dukungan sosial mengacu pada penerimaan atau pertolongan, kepedulian, penghargaan, atau bantuan yang dirasakan individu yang diterima dari orang lain atau kelompoknya. Hal ini sesuai dengan pernyataan dari Taylor bahwa, dukungan sosial adalah informasi dari orang yang dicintai dan dipedulikan, dihormati dan dihargai, serta bagian dari hubungan dan kewajiban bersama (Revenson \& Gurung, 2019). Dukungan sosial yang diberikan orang-orang yang terdekat, orang yang dicintai dan dihormati individu akan lebih bermanfaat daripada dukungan dari orang asing atau yang memiliki hubungan jauh dengan individu.

Parental involvement is not limited to encouragement, support from the parent to the child but can be more assimilated when the parents act by example e.g. the parent activeness in sports can motivate the child participation while on the other hand, the inactiveness of the parent toward sports can also have an effect on the child's motivation to participate (Mbong, 2017). Apabila diterjemahkan yakni, Keterlibatan orang tua tidak terbatas pada dorongan, dukungan dari orang tua kepada anak tetapi dapat diasimilasi ketika orang tua bertindak dengan contoh keaktifan orang tua dalam olahraga dapat memotivasi anak berpartisipasi aktif berpartisipasi aktif berpartisipasi dalam motivasi anak untuk berpartisipasi.

Menurut (Woody, 2005), dukungan sosial adalah kenyamanan secara fisik dan psikologis yang diberikan oleh teman atau anggota keluarga. Dukungan sosial dapat diperoleh individu dari orangorang terdekat, yaitu teman, pasangan, dan keluarga atau orang tua. Dukungan sosial orang tua adalah kenyamanan secara fisik dan psikologis yang diberikan oleh orang tua kepada anak. Hal ini sesuai dengan beberapa hasil penelitian, salah satunya yakni, (Caron et al., 2006) also emphasizes that previous research has proven that parental participation in sports has a buge effect for the female athlete. (Estes et al., 2009) found that a mother's participation in sports has an impact in predicting young girls continues participation in both school and community sports. Apabila diterjemahkan yakni, bahwa penelitian sebelumnya telah membuktikan bahwa partisipasi orang tua dalam olahraga memiliki efek yang sangat besar bagi atlet wanita. Partisipasi ibu dalam olahraga memiliki dampak dalam memprediksi remaja putri melanjutkan partisipasi dalam olahraga sekolah dan komunitas.

Terdapat empat macam bentuk dukungan yaitu dukungan instrumental (tangible assistance), informasional, emosional dan harga diri. Hal yang berpengaruh terhadap kesuksesan akademis anak adalah dukungan orang tua, gambaran diri yang positif, perilaku remaja, harga diri, motivasi dan kesehatan mental (Susanto, Sulastri, Listyorini, 2013). Keterlibatan orang tua dihubungkan dengan prestasi sekolah dan emosional serta penyesuaian selama sekolah pada remaja. Dukungan sosial erat kaitannya dengan harga diri atau self esteem, hal ini terjadi karena ketika anak memiliki dukungan social yang positif maka factor psikologis seperti harga diri semakin meningkat. Self-esteem dapat didefinisikan sebagai penilaian diri yang dilakukan oleh seorang individu terhadap dirinya sendiri. Penilaian tersebut mencerminkan sikap yang menunjukkan seberapa jauh individu percaya bahwa dirinya mampu, penting, berhasil serta berharga (Marsh, 1990). Self-esteem, disini berkaitan dengan bagaimana individu mempersepsikan dirinya dalam arti penghargaan secara keseluruhan. Self-esteem berkembang bersamaan dengan pengalaman-pengalaman seseorang dari hasil interaksi dengan lingkungan sosial (Hurlock, 2001). Pengembangan self-esteem akan memakan waktu yang sangat panjang dan berkorelasi dengan pembentukan citra diri dan hati Nurani (Manning, Bear, \& Minke, 
2006). Harga diri adalah konstruksi utama dalam psikologi, perkembangan, kepribadian, dan sosial, dan perannya dalam fungsi psikologis telah dipelajari selama hampir satu abad (Abdel-Khalek, 2016).

Sejalan dengan bentuk stress dan segala hal yang berhubungan dengan perubahan kehidupan yang timbul saat masa remaja, seseorang harus memiliki pegangan yang kuat atas kesehatan emosi mereka. Kesehatan emosi dibangun berdasarkan fondasi dari pikiran positif dan self-esteem yang sehat. Selfesteem dapat dilihat sebagai komponen gambar diri (Wojtas, Oskedra, Cepuch, \& Świderska, 2014). Dari semua penghakiman kita, tidak satupun yang sepenting yang kita berikan terhadap diri kita sendiri. Self-esteem yang positif merupakan kebutuhan pokok untuk menjalani hidup "Apart from problems that are biological in origin, I cannot think of a single psychological difficulty-from anxiety and depression, to fear of intimacy or of success, to alcohol or drug abuse, to underachievement at school or at work, to spouse battering or child molestation, to sexual dysfunctions or emotional immaturity, to suicide or crimes of violence-that is not traceable to poor self-esteem. Of all of the judgments we pass, none is as important as the one we pass on ourselves. Positive self-esteem is a cardinal requirement of a fulfilling life" (Myers-Clack \& Christopher, 2001).

Self-esteem merupakan dasar dari kesehatan emosi. Ada banyak aktivitas dan lebih banyak informasi yang membatu mentor dalam menolong anak didiknya membangun self-esteem dan mengatasi masalah yang disebabkan self-esteem yang rendah. (Mulyadi, Rahardjo, \& Basuki, 2016) menyebutan bahwa, anak dengan tingkat harga diri positif dianggap memiliki kemampuan untuk memenuhi setiap tantangan. Self-esteem juga merupakan sumber dari banyak penyakit seseorang yang akan berakibat buruk bagi orang lain. Selfesteem merupakan hal yang paling peka, penting bagi para mentor untuk mengobservasi anak didiknya, berbicara kepada mereka tentang bagaimana perasaan mereka terhadap diri mereka sendiri, dan menolong mereka menemukan cara untuk melihat nilai diri mereka sendiri.

\section{Simpulan dan Rekomendasi}

Kesimpulan dari penelitian ini adalah (a) dukungan sosial orangtua memberikan pengaruh yang besar terhadap self-esteem. Hal ini dibuktikan dengan uji signifikansi variable $\mathrm{X}$ terhadap $\mathrm{Y}$ yang menunjukkan hasil $\mathrm{Y}=\mathrm{a}+\mathrm{b} \mathrm{X} 1=222,109+0,729 \mathrm{X} 1$ persentase yang diperoleh antara $\mathrm{X}$ terhadap $\mathrm{Y}$ adalah $0,405 \times 100 \%=40,5 \%$. (b) Dukungan sosial orangtua memberikan pengaruh yang signifikan terhadap self-esteem. Hal ini dibuktikan dengan uji peningkatan yang menunjukkan nilai $t_{\text {hitung }}$ dengan $t_{\text {tabel, }}$, ternyata teridentifikasi bahwa thitung $=4,568$ lebih besar daripada ttabel $=1,697$, atau nilai sig. lebih kecil dari taraf signifkansi 0,05 yaitu 0,047 , sehingga dapat disimpulkan bahwa persamaan regresi dukungan sosial $(\mathrm{X})$ terhadap self esteem $(\mathrm{Y})$ adalah signifikan.

Berdasarkan kesimpulan dari hasil penelitian di atas, maka penulis menyampaikan rekomendasi sebagai berikut: (a) Bagi pelatih, guru diharapkan dalam melatih dan membina anak, harus lebih memperhatikan faktor psikologis anak dari segi dukungan sosial orangtua, karena peran penting keluarga sangatlah menentukan kondisi anak dikemudian hari. (b) Bagi peneliti selanjutnya yang akan meneliti dengan masalah yang serupa, diharapkan menggunakan sampel yang lebih banyak dan waktu yang lebih lama serta pada level yang lebih tinggi

\section{Ucapan Terima Kasih:}

Penulis mengucapkan terima kasih atas partisipasi, dukungan dan kerjasamanya kepada tim Kabupaten Sumedang di ajang O2SN Jawa Barat, pelatih dan official berbagai cabang olahraga dan berbagai pihak lainnya yang terlibat pada penelitian ini. 


\section{Daftar Pustaka:}

Abdel-Khalek, A. M. (2016). Introduction to the psychology of self-esteem. Self-Esteem: Perspectives, Influences, and Improvement Strategies, 1-17.

Akbar, R. (2001). Hawadi. Psikologi Perkembangan Anak: Mengenal Sifat, Bakat, dan Kemampuan Anak. Jakarta: Grasindo.

Caron, A., Weiss, B., Harris, V., \& Catron, T. (2006). Parenting behavior dimensions and child psychopathology: Specificity, task dependency, and interactive relations. Journal of Clinical Child and Adolescent Psychology, 35(1), 34-45.

Clement, D., \& Shannon, V. R. (2011). Injured athletes' perceptions about social support. Journal of Sport Rehabilitation, 20(4), 457-470.

Estes, A., Munson, J., Dawson, G., Koehler, E., Zhou, X.-H., \& Abbott, R. (2009). Parenting stress and psychological functioning among mothers of preschool children with autism and developmental delay. Autism, 13(4), 375-387.

Fischer, J., \& Corcoran, K. (2007). Measures for clinical practice and research: A sourcebook volume 1: Couples, families, and children (Vol. 1). Oxford University Press.

Fisher, A., Reilly, J. J., Kelly, L. A., Montgomery, C., Williamson, A., Paton, J. Y., \& Grant, S. (2005). Fundamental movement skills and habitual physical activity in young children. Medicine \& Science in Sports \& Exercise, 37(4), 684-688.

Hurlock, E. B. (2001). Developmental psychology. Tata McGraw-Hill Education.

Lengkana, A. S. (2013). Pengaruh Kids'athletics Terhadap Self-Esteem Dan Kebugaran Jasmani: Studi Ex Post Facto pada Siswa Sekolah Atletik Pajajaran. Universitas Pendidikan Indonesia.

Linver, M. R., Brooks-Gunn, J., \& Kohen, D. E. (2002). Family processes as pathways from income to young children's development. Developmental Psychology, 38(5), 719.

Maksum, A. (2012). Metode penelitian dalam olahraga. Solo: Unesa University Press.

Manning, M. A., Bear, G. G., \& Minke, K. M. (2006). Self-Concept and Self-Esteem.

Marsh, H. W. (1990). A multidimensional, hierarchical model of self-concept: Theoretical and empirical justification. Educational Psychology Review, 2(2), 77-172.

Mbong, C. F. (2017). Parental Involvement in Youth Sports and Physical Activities.

Mulyadi, S., Rahardjo, W., \& Basuki, A. M. H. (2016). The role of parent-child relationship, selfesteem, academic self-efficacy to academic stress. Procedia-Social and Behavioral Sciences, 217, 603608.

Myers-Clack, S. A., \& Christopher, S. E. (2001). Effectiveness of a health course at influencing preservice teachers' attitudes toward teaching health. Journal of School Health, 71(9), 462-466.

Revenson, T. A., \& Gurung, R. A. R. (2019). Handbook of health psychology. Routledge.

Setyaningrum, A. (2015). Pengaruh dukungan sosial orang tua terhadap motivasi berprestasi siswa kelas v sekolah dasar. basic education, 4(17).

Stainback, S., \& Stainback, W. (1988). How to help your child succeed in school. Simon \& Schuster.

Sumoprawiro, S. (2009). Prestasi Olahraga Indonesia. Online At.

Susanto, D. N., Sulastri, B., pM Kes, S. K., Listyorini, D., \& S Kep, N. (2013). Hubungan Antara Dukungan Negatif Orang Tua Dengan Perilaku Merokok Remaja Di Desa Puro Kecamatan Karangmalang Kabupaten Sragen. Universitas Muhammadiyah Surakarta. 
Wojtas, K., Oskedra, I., Cepuch, G., \& Świderska, E. (2014). The level of negative emotions, coping with stress and social support for parents of children suffering from epilepsy. Folia Medica Cracoviensia, 54(1), 79-86.

Woody, R. H. (2005). The Police Culture: Research Implications for Psychological Services. Professional Psychology: Research and Practice, 36(5), 525. 